indebted to the Department of Scientific and Industrial Research for a research studentship.

E. A. Bevan

R. F. O. KEMP

Department of Botany,

University of Oxford. Feb. 24.

'Plunkett, B. E., Ann. Bot., 17, 193 (1953).

2 Aschan, K., Physiol. Plantarum, 7, 571 (1954).

\section{A Soil-borne Virus associated with the Corky Ringspot Disease of Potato}

A SAP-TRANSMISSIBLE rod-shaped virus which is carried in the soil has been recovered from corky ringspot-affected Sebago potato tubers and from a certain percentage of potato plants produced from diseased tubers. The virus has also been recovered from systemically infected potato seedlings, pepper and tobaceo when these plants were grown in the greenhouse in virus-contrining loamy fine sand soil, obtained from the site of field infection in northern Florida.

The virus has been named the 'potato corky ringspot virus' $(P C R V)$ and is distinguished readily from potato viruses $A, F, M, S, X$ and $Y$. A relationship between it and the soil-borne potato stem-mottle, and tobacco rattle viruses from the Netherlands, has been established serologically. Because it is associated with symptoms in potato tubers differing from those reported for the latter two viruses, the above specific name has been applied. Precipitation with 50 per cent saturated ammonium sulphate did not cause a decrease in infectivity of new virus. The virus was infective in undiluted tobacco sap heated for 10 min. at $80^{\circ} \mathrm{C}$., but not in sap heated at $90^{\circ} \mathrm{C}$.

The exact relationship between a virus isolated from corky ringspot diseased potato tubers, first reported in $1946^{1}$ from the potato-growing area of Hastings, Florida, and a soil-borne virus isolated from systemically infected potato seedlings, is being examined. Reports of a type of corky ringspot of potato tubers from Indiana and Washington are also being investigated.

Department of Plant Pathology,

C. H. Walkinshaw R. H. LARSON

University of Wisconsin,

Madison 6, Wisconsin,

Feb. 6.

"Eddins, H. A., Procter, E. Q., and West, Erdman, Plant Disease Report, 30, 232 (1946); Amer. Potato J., 23, 330 (1946).

\section{Bugula simplex Hincks, a Newly Recognized Polyzoan from British Waters}

IN September 1957, a species of Bugula was discovered at Holyhead, North Wales, which did not conform to any of the species described by Hincks ${ }^{1}$. Reference to the literature showed that it resembled the B. flabellata of American authors, although it was, in fact, clearly not B. flabellata (Thompson). Osburn ${ }^{2}$ identified the American form as B. flabellata and noted that Woods Hole material did not conform completely to the description given by Hincks ${ }^{1}$, although he evidently did not appreciate the full extent of the differences. Since the species is common in the Woods Hole area on submerged piles ${ }^{2}$ and has been the subject of extensive experiments, notably by Lynch $^{8}$, its proper identification is of importance.
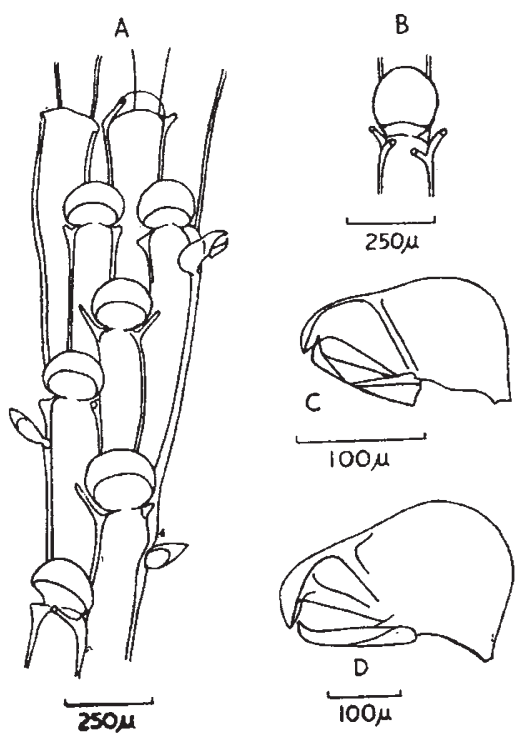

Fig. 1. A, Bugula simplex, portion of branch showing hemispherical ovicells and single spines on zocecial angles; $\boldsymbol{B}, \boldsymbol{B}$. flabellata, distal end of zocelum showing globular ovicell and two spines on each zocecial angle; $C$, avicularium of $B$. simplex; $D$
from marginal zocecium of $B$. flabellata

Hastings (private communication) told me that the British Museum (Natural History) had specimens of this type sent by Verrill from North America, and also from Lowestoft, which were probably the same as $B$. sabatieri Calvet ${ }^{4}$; further, $B$. sabatieri might be a synonym of $B$. simplex Hincks. No type specimen of $B$. sabatier $i$ has been seen, but Calvet's description closely fits the form being discussed, which is, however, identical with the type of B. simplex. As the latter name has priority the species must be called $B$. simplex Hincks.

Descriptions of $B$. simplex are given by Hincks ${ }^{5}$, Calvet $^{4}$ (as B. sabatieri) and Osburn ${ }^{2}$ (as B. flabellata). A description of true $B$. flabellata is given by $\mathbf{H i n c k s}^{1}$. In fact, although both species have zoœcia arranged in several rows, $B$. simplex is readily distinguishable from $B$. flabellata (Fig. 1).

The most obvious diagnostic charrcters of $B$. simplex are: the almost hemispherical ocecia; the restriction of the avicularia to the marginal series of zoceia ; and the presence of only one, less often two, spines on each of the distal angles of the zoceia. In $B$. flabellata the oceia are almost globular; avicularia are present on both the inner and the marginal series of zoœcia, although the former are much smaller than the latter; and the number of spines on each distal angle is two, or three on the outer angles of the marginal sories of zoccia. The avicularia of $B$. simplex are quite characteristic in shape, with a rather long head and $a$ down-curved beak, although these points are not brought out in Calvet's ${ }^{4}$ figure.

Spocimens of $B$. simplex in the British Museum (Natural History) have been obtained from the Adriatic (type specimen), the British Isles (Lowestoft) and the Atlantic coast of North America (Woods Hole and Noank, Conn.). As the specimen from Lowestoft was collected from the lifeboat in 1893, or earlier, there can be no question of the species being a recent introduction to Britain. As $B$. sabatieri the species has been recorded from the Mediterranean coast of France ${ }^{4}$. 